Abstracta Iranica Abstracta Iranica

Revue bibliographique pour le domaine irano-aryen

Volume 22 | 2001

Comptes rendus des publications de 1999

Majlis ${ }_{20}^{E O}$ Discours sur l'Ordre et la création. Trad. avec introd. et notes de la dernière édition de Jalālī Nā'innī par Diane Steigerwald, Québec, Les Presses de l'Université de Laval, 1998, 168 p.

\title{
Pierre Lory
}

\section{(2) OpenEdition}

\section{Journals}

Édition électronique

URL : http://journals.openedition.org/abstractairanica/36792

DOI : 10.4000/abstractairanica.36792

ISSN : 1961-960X

Éditeur :

CNRS (UMR 7528 Mondes iraniens et indiens), Éditions de l'IFRI

Édition imprimée

Date de publication : 15 mai 2001

ISSN : 0240-8910

Référence électronique

Pierre Lory, «Majlis 堅 Discours sur l'Ordre et la création. Trad. avec introd. et notes de la dernière édition de Jalālī Nāinī par Diane Steigerwald, Québec, Les Presses de l'Université de Laval, 1998, 168 p. », Abstracta Iranica [En ligne], Volume 22 | 2001, document 351, mis en ligne le 17 février 2010, consulté le 13 octobre 2020. URL : http://journals.openedition.org/abstractairanica/36792 ; DOI : https:// doi.org/10.4000/abstractairanica.36792

Ce document a été généré automatiquement le 13 octobre 2020.

Tous droits réservés 


\section{Majlis ${ }_{20}^{[D}$ Discours sur l'Ordre et la création. Trad. avec introd. et notes de la dernière édition de Jalālī Nā'īnī par Diane Steigerwald, Québec, Les Presses de l'Université de Laval, 1998, 168 p.}

\section{Pierre Lory}

1 Le présent ouvrage se situe dans la continuation de recherches antérieures où D. Steigerwald s'attachait à démontrer que Šahrastānī avait adopté des positions ismaéliennes (Abs. Ir. 20-21, c.r. $n^{\circ} 485$ ). Le Majlis constitue de fait l'une des pièces maîtresses du dossier. Il est ici présenté accompagné de son texte persan (éd. G. Nā'īnī de 1990) avec la traduction française en regard. Il s'agit d'un exposé assez bref (trente pages dans le texte persan imprimé) mais dense et structuré portant sur la cosmogonie (distinction entre les plans de l'Ordre, Amr, et de la Création, Halq) et l'accès à la connaissance. La ressemblance avec la démarche des penseurs ismaéliens fatimides comme al-Sijistānī ou al-Kirmānī ou avec les textes nizārites plus tardifs s'impose d'elle-même. Quelques allusions aux cycles prophétiques, à 'Alĩ ibn Abī Țālib et à ses deux fils suggèrent par ailleurs une doctrine imamologique. Une introduction de 65 pages présente le texte et sa traduction. L'ensemble de l'introduction est d'ailleurs abondamment annoté et doté d'index complets, et facilite considérablement l'accès à une pensée décidément bien surprenante dans son ampleur comme dans ses détours. 
INDEX

Thèmes : 7. Islam

\section{AUTEURS}

PIERRE LORY

EPHE - Paris 